\title{
The cattle slurry virome and the potential spread of antibiotic resistance
}

Ryan Cook

Steven Hooton

Urmi Trivedi

Liz King

Christine Dodd

Jon Hobman

Dov Stekel

Michael Jones

Andrew Millard

\section{Video Byte}

Keywords: Microbiome, phages, viromics, VapE, diversity-generating retroelements, crAssphage, PromethION, slurry, dairy, cattle, bacteriophages, veterinary pathogens, virulence factors, putative antibiotic resistance genes, ARGs

Posted Date: October 15th, 2021

DOI: https://doi.org/10.21203/rs.3.rs-969879/v1

License: (c) (1) This work is licensed under a Creative Commons Attribution 4.0 International License. Read Full License 


\section{Abstract}

Livestock waste is a common fertilizer for crop fields. Many farms remove the solids from manure and store only the remaining liquid, called slurry, for later use, but little is known about the microbial contents of slurries, especially the viruses. To close this gap, researchers sequenced the slurry virome of a cattle farm over a 5-month period. They used a hybrid approach, combining short and long sequencing reads, which provided more comprehensive results than using only one method. The farm's virome was dominated by lytic bacteriophages and $98 \%$ were from novel genera. The overall diversity and composition was stable over time. In fact, over half of the operational taxonomic units were detected in all the samples. Functional analysis found a range of metabolic genes, diversity-generating retroelements, putative antibiotic resistance genes, and virulence factors. These results mean that spreading slurry may allow phages to spread those virulence and antibiotic resistance genes to bacterial pathogens. Some of these specific virulence factors, such as vapE, are found in agricultural pathogens like_Streptococcus_spp., which causes mastitis in cows. The prevalence of virulence factors in this system warrant further investigation to determine if they are being spread to pathogens in fields. 